\title{
Breathing and relaxation training for patients with hypertension and stress
}

\author{
Treino de relaxamento e respiração em \\ pacientes com hipertensão e estresse
}

\author{
Livia de Matos CHICAYBAN ${ }^{1}$ \\ Lucia Emmanoel Novaes MALAGRIS'
}

\begin{abstract}
This study evaluated the effects of the relaxation and breathing training for hypertensive patients on the index, levels and symptoms of stress and blood pressure among hypertensive patients suffering from stress. Nineteen patients from a hypertension and diabetes program in Rio de Janeiro participated in the study that which used, as instruments, Lipp's inventory of stress symptoms for adults, the psychological interview for hypertensive patients, the relaxation and breathing training for hypertensive patients protocol, weekly registration form and blood pressure monitors. The experimental group received the relaxation and breathing training for hypertensive patients in 13 sessions of 60 minutes and had blood pressure monitored before and after each session. The control group had blood pressure monitored weekly. It was observed that the relaxation and breathing training for hypertensive patients reduced the stress index and symptoms in the experimental group in isolation, except when compared to the control group. However, it did not reduce the levels of blood pressure in the experimental group in comparison to the control group. The results report that, besides the relaxation and breathing training for hypertensive patients, other strategies are necessary to control stress and hypertension.
\end{abstract}

Keywords: Blood pressure; Hypertension; Stress; Relaxation therapy.

\section{Resumo}

Este estudo avaliou os efeitos do treino de relaxamento e respiração para hipertensos no índice, níveis, sintomas de stress e pressão arterial de hipertensos estressados. Participaram do estudo 19 pacientes de um programa de hipertensão e diabetes do Rio de Janeiro, utilizando-se como instrumentos o inventário de sintomas de stress para adultos de Lipp, entrevista psicológica para hipertensos, protocolo e folha de registro semanal do treino de relaxamento e respiração para hipertensos e esfigmomanômetro. O grupo experimental submeteu-se ao treino de relaxamento e respiração

rr

1 Universidade Federal do Rio de Janeiro, Instituto de Psicologia, Programa de Pós-Graduação em Psicologia. Av. Pasteur, 250, Fundos, $2^{\circ}$ andar, Praia Vermelha, 22290-902, Rio de Janeiro, RJ, Brasil. Correspondência para/Correspondence to: L.E.N. MALAGRIS E-mail: <lucianovaes@terra.com.br>.

Article based on the dissertation of L.M. Chicayban intitled "Stress e Hipertensão: treino de relaxamento e respiração como método de intervenção". Universidade Federal do Rio de Janeiro, 2009.

Support: Coordenação de Aperfeiçoamento de Pessoal de Nível Superior.

Acknowledgments: Centro Municipal de Saúde Marcolino Candau and the trainees Anna C. Andrade, Carla Telles, Gabriela Lima and Luciana Bento, for their collaboration in the study field work. 
para hipertensos em 13 sessões de 60 minutos e teve pressão arterial aferida antes e após cada sessão. O grupo-controle compareceu semanalmente para aferir pressão arterial. Verificou-se que o treino de relaxamento e respiração para hipertensos reduziu índice e sintomas de stress no grupo experimental, isoladamente, exceto na comparação com o grupo-controle; contudo, não reduziu níveis de pressão arterial do grupo experimental, comparado ao grupo-controle. Os resultados indicam que, além do treino de relaxamento e respiração para hipertensos, outras estratégias parecem necessárias para controle do stress e da hipertensão.

Palavras-chave: Pressão arterial; Hipertensão; Estresse; Terapia de relaxamento.

It was in the early 1930s that Selye (1965) commenced his studies on stress in the area of health, concluding that it was a matter of a complex, dynamic neuropsychophysiological process which takes place over three stages (alarm, resistance and exhaustion). According to the author, stress has an adaptive function and when chronic, it may contribute to the development of various diseases (cardiovascular, renal, arthritis, hypertension, ulcers and cancer). Based on her field research, Lipp (2000) concluded that the stress process occurs in four phases (alert, resistance, near-exhaustion and exhaustion) which, when it reaches the advanced phases, involves a significant degree of impairment of the organism (Lipp \& Malagris, 2011).

As far as Lipp (Lipp \& Malagris, 2001, p.477) is concerned, stress can be defined as "the organism's reaction to psychological and physical components, caused by psychophysiological alterations which occur when an individual is confronted with a situation which in some way irritates, scares, excites or confuses him or even makes him immensely happy". It is already known that thoughts and mental processes play a clear role in stress (Lazarus \& Folkman, 1984). As for the emotions, they sustain stress, activating physiological alterations which comprise the stress response and negative emotions contribute significantly to the psychological and physical effects of stress (Lipp, Malagris, \& Novais, 2007, Straub, 2005), which include, amongst others, the development of high blood pressure (Davis, Eshelman \& McKay, 2000).

The $5^{\text {th }}$ and $6^{\text {th }}$ Brazilian Guidelines on Arterial Hypertension (Mion et al., 2007; Sociedade Brasileira de Cardiologia, Sociedade Brasileira de Hipertenção e Sociedade Brasileira de Nefrologia, 2010), emphasize that Systemic Arterial Hypertension 116 $(\mathrm{SAH})$, or high arterial Blood Pressure (BP), is a multifactorial disease which represents an independent, significant risk factor in the occurrence of cardiovascular diseases and stroke Cerebral Vascular Accident (CVA), giving rise to a high level of hospitalization resulting from the complications of these diseases and posing a high medical and socioeconomic cost. Accordingly, a close link has been suggested between emotional stress and high BP. Amongst the risk factors for the development, maintenance and aggravation of hypertension, such as age (Daugherty et al., 2011), gender (Sandberg \& Ji, 2012), family history (Souza et al., 2009), race (Carson et al., 2011), obesity, sedentary lifestyle, use of alcohol, tobacco, birth control drugs and food rich in sodium and fats (Forman, Stampfer, \& Curhan, 2009), emotional stress is prominent (Lipp \& Rocha, 1994, 2008; Malagris et al., 2009). For this reason, the $6^{\text {th }}$ Brazilian Guidelines on Arterial Hypertension (Sociedade Brasileira de Cardiologia - SBC et al., 2010) emphasize the need for stress management programs as a fundamental, nonpharmacological step in the treatment of hypertension.

Aspects such as the cost of continuous treatment with antihypertensive drugs, the potential lack of transparency with regard to the doctorpatient relationship, the multiple medications sometimes prescribed and the collateral effects of these drugs (Pimenta, Calhoun, \& Oparil, 2007), have served to explain and encourage the quest for nonpharmacological approaches to controlling arterial pressure, such as complementary treatment. Studies have found that the use of a multidisciplinary approach, comprising clinical, pharmacological treatment and a program of intervention to control the risk factors, is more effective in reducing the rate of cardiovascular mortality and morbidity than treatment which is exclusively drug-based (Khan et al., 2007; Pugliese et al., 2007; Sociedade Brasileira de Cardiologia et al., 2010). 
One of these approaches, which complements the use of drugs, has been the technique of relaxation, capable of making the body maintain a calmer, more balanced state, having an effect also on mental relaxation. Various types of relaxation techniques exist, including Progressive Muscular Relaxation (PMR) developed by Jacobson in 1929 (Jacobson, 1938, 1993) which has proved to be effective, non-invasive, simple, easy to learn and capable of bringing a reduction in BP in hypertensive individuals (Sheu, Irvin, Lin, \& Mar, 2003). Jacobson's initial argument was that, given anxiogenic thoughts or events, the body reacts with muscular tension and that progressive muscular relaxation, through a reduction of tension from region to region of the body, leads to overall relaxation.

Another non-pharmacological approach to the treatment of hypertension is breathing training. Lipp and Rocha (1994) point out that hypertensive individuals tend to present with superficial breathing and, as a result, the level of carbon dioxide in the blood rises, prompting respiratory acidosis. According to these authors, correct breathing occurs through a spacious inhalation that is deep, slow and uses both nostrils. It should be emphasized that exhaling should be slower, via the mouth and should take twice as long as it takes to inhale. Slow, regular breathing produces beneficial effects in the cardiovascular reflex control system, including an increase in cardiorespiratory endurance and baroreflex sensitivity, reduction in BP (Thalenberg, 2006; Thalenberg et al., 2008; C.H.J. Pinheiro, Medeiros, Pinheiro, \& Marinho 2007) and an increase in oxygen saturation in acute myocardial infarction (E. Grossman, Grossman, Shein, \& Zimlichman, 2001). Pinheiro et al. (2007), carrying out treatment with a slow breathing technique with hypertensive patients, obtained important results in respect of the cardiovascular system: the modification in the respiratory pattern improved cardiovascular control in hypertension, through the reduction in Systolic Blood Pressure (SBP), Diastolic Blood Pressure (DBP), reduction in respiratory frequency as well as other hemodynamic parameters evaluated in the study.

The benefits for BP of relaxation and slow, deep breathing have been observed in hypertensive individuals using stress control programs such as Lipp's Stress Control Training (Lipp, 1991, 2007) and the stress control program developed and administered by Lucini, Riva, Pizzinelli and Pagani (2008) on employees in an Italian multinational company. These authors emphasize that deep, diaphragmatic breathing and muscle relaxation, when applied in conjunction, are shown to be useful strategies for controlling excessive stress. In Lipp's stress control program, a reduction was found in the levels of stress and BP. In the SCP developed by Lucini et al. (2008), a reduction in the level of stress, a reversal in the deregulation of the Autonomous Nervous System through physiological parameters and a reduction in SBP were all observed.

The aims of the present study were to: (a) compare the index, level (phase) and number of stress symptoms, identified using Inventário de Sintomas de Stress para Adultos de Lipp (ISSL, Lipp's Adult Stress Symptoms Inventory), after practicing Relaxation and Breathing Training for Hypertensive Patients (RBTHP) in the Experimental Group (EG), in relation to the passage of time, with the Control Group (CG); (b) compare the levels of basal blood pressure (SBP and DBP) in stressed, hypertensive patients after practicing RBTHP in the EG, compared to the CG.

\section{Method}

\section{Participants}

A total of 19 patients with hypertension in stage 1 (mild hypertension) and stage 2 (moderate hypertension) took part in the study, all of whom were treated in the Hypertension and Diabetes Program at the Centro Municipal de Saúde Marcolino Candau (CMSMC, Marcolino Candau Municipal Health Center), which is a part of the Sistema Único de Saúde (SUS, Brazilian National Health System). The patients were monitored by a Program doctor, making use of anti-hypertensive medication which varied according to specific individual needs. Four participants, 2 from the Experimental Group (EG) and 2 from the Control 
Group (CG), were excluded from the sample as they only showed up for one session. So the initial sample, comprising 23 participants, was reduced to 19,9 in the $E G$ and 10 in the $C G$, including, respectively, 5 women and 4 men (EG) and 9 women and 1 man (CG). As far as age range is concerned, the participants had an average age of $54.26 \pm 8.97$.

The inclusion/exclusion criteria for participation in the study were as follows: being stressed from the Resistance phase, as per the ISSL; being aged between 30 and 65; undergoing medical treatment for hypertension; not using psychotropic drugs; not being diabetic; not having suffered an Acute Myocardial Infarction (AMI); not having suffered a stroke (CVA); not suffering from chronic renal disease, ischemic myocardiopathy or known serious mental disorders; being literate; not undergoing psychotherapy and not being an expectant mother.

\section{Instruments}

The following materials and instruments were used: Informed Consent Form (ICF); ISSL (Lipp, 2000, 2005) for an evaluation of the presence, phase and symptoms of stress; psychological interview for hypertensive patients, relaxation and breathing training protocol for hypertensive patients (Lipp \& Rocha, 2008); weekly record sheet of relaxation and breathing training for Hypertensive Patients (WRS-RBTHP), handed out every week to the participants for them to fill in each day at home with the days of the week on which the relaxation and breathing exercises were carried out and returned to the team at the time of the next session, when the participant would receive a new WRS-RBTHP and finally, a calibrated analog pressure device, or sphygmomanometer, certified and approved by Instituto Nascional de Meterologia, Qualidade e Tecnologia (InMetro, Brazil's National Institute of Metrology, Quality and Technology).

\section{Procedures}

This research was part of a wider study which 118 aimed to compare Lipp's full SCT with the use of relaxation and breathing techniques created on one of the SCT pillars, already approved by the Municipal Health Department's Commission of Ethics in Research on Human Beings. The procedure for the study expounded here is based on the application of the RBTHP protocol, in 13 weekly sessions each lasting 60 minutes.

After signing the ICF, the patients were submitted to Psychological Interview for Hypertensive Patients and to the ISSL. In the EG, evaluations were carried out both before and after the RBTHP while in the CG, before and after the period of time proportional to that used for the RBTHP (13 weeks). The groups were composed according to order of arrival at the interviews. The first members of the sample were assigned to the $E G$, until the appropriate number of participants was arrived at for the performance of the RBTHP, while the others were assigned to the CG.

The Relaxation and Breathing Training for Hypertensive Patients was forecast to be carried out in 12 weekly sessions of 60 minutes each (30 minutes relaxation and breathing exercises and 30 minutes preparation of the participants and measurement of blood pressure), based on Lipp's SCT (Lipp, 1991). In order to teach the relaxation and slow, deep breathing technique to the participants, an experimental session was conducted, so in fact there were 13 sessions in total. The participants' BP was checked at the beginning and at the end of the RBTHP sessions, following the patient preparation and pressure measurement procedures recommended by the $5^{\text {th }}$ Brazilian Guidelines on Hypertension (Mion Jr. et al., 2007). In each session, the patients in the $E G$ received the WRS-RBTHP to fill in at home every day, in which they were to mark the days of the week they performed the exercises. As for the participants in the $C G$, they were asked to turn up at the CMSMC every week for 13 weeks to check their BP.

At the end of the intervention period, the participants in both groups were reassessed using the ISSL in the last RBTHP session, and in the CG after 13 weeks, in order to check for changes in the stress diagnosis, level of stress and levels of basal $B P$. The criteria for checking the effectiveness of the RBTHP were the reduction in SBP and DBP, as 
well as a reduction in the level of stress and the number of physical and/or psychological symptoms of stress.

\section{Results}

The data obtained were input to Microsoft ${ }^{\circledR}$ Office Excel 2003 spreadsheets, enabling the calculation of means and standard deviations for each variable. To analyze the results, the programs SPSS 13.0 for Windows and SAS System for Windows, version 8.02 were used. In all the tests applied, a level of significance of $5 \%(p<0.05)$ was used.

Analyzing the EG separately, the reevaluation indicated that, after the RBTHP, 5 (55.6\%) patients no longer presented with stress and 4 (44.4\%) continued to experience stress. As for the CG, after the period of 13 weeks, only 1 (10.0\%) patient ceased to present with stress, as opposed to the 9 remaining patients $(90.0 \%)$, who continued to be stressed. Analyzing each group separately, there was a significant difference $(p=0.029)$ in the $E G$, taking into account the pre- and post-intervention, in terms of the stress index, indicating that there was a reduction in the number of stressed individuals in the group. In the $C G$, on the other hand, this was not the case $(p=1)$ (Tables 1 and 2$)$. Comparing the $E G$ and $C G$ in terms of the stress index after the RBTHP, a marginally insignificant difference was found ( $p=0.057$ ). Therefore there was no significant reduction in the index of stressed individuals in the EG after the RBTHP, compared to the CG.

In Table 3, the patients in each group are characterized as to the diagnosis and symptomology of stress found in the ISSL in the initial assessment, and again at the end of the study, in the reassessment. As for stress levels, it was found that in the EG, prior to intervention, 6 participants $(67.0 \%)$ were in the Resistance phase, while 3 (33.0\%) were in the Near-Exhaustion phase. In the CG, on the other hand, 7 patients $(70.0 \%)$ were identified in the Resistance phase, while 3 (30.0\%) received a diagnosis of Near-Exhaustion. A similar distribution was observed, therefore, between the

Table 1

Stress index in the groups before and after the intervention. Rio de Janeiro (RJ), 2008

\begin{tabular}{|c|c|c|c|c|c|c|c|c|c|c|c|c|c|}
\hline \multirow{4}{*}{ Timing } & \multicolumn{13}{|c|}{ Presence of stress } \\
\hline & \multicolumn{6}{|c|}{ Yes } & \multicolumn{6}{|c|}{ No } & \multirow{3}{*}{$\begin{array}{c}p \text { value } \\
\text { Intergroup }\end{array}$} \\
\hline & \multicolumn{2}{|c|}{$\mathrm{EG}(\mathrm{n}=9)$} & \multicolumn{2}{|c|}{$C G(n=10)$} & \multicolumn{2}{|l|}{ Total } & \multicolumn{2}{|c|}{$\mathrm{EG}(\mathrm{n}=9)$} & \multicolumn{2}{|c|}{$C G(n=10)$} & \multicolumn{2}{|l|}{ Total } & \\
\hline & Frequence & $\%$ & Frequence & $\%$ & Frequence & $\%$ & Frequence & $\%$ & Frequence & $\%$ & Frequence & $\%$ & \\
\hline Pre & 9 & 100.0 & 10 & 100.0 & 19 & 100.0 & 0 & 0 & 0 & 0 & 0 & 0 & * \\
\hline Total & 9 & 100.0 & 10 & 100.0 & 19 & 100.0 & 9 & 100.0 & 10 & 100.0 & 19 & 100.0 & \\
\hline Post & 4 & 44.4 & 9 & 90.0 & 13 & 68.4 & 5 & 55.6 & 1 & 10.0 & 6 & 31.6 & $p=0.057$ \\
\hline Total & 9 & 47.4 & 10 & 52.6 & 19 & 100.0 & 9 & 47.4 & 10 & 52.6 & 19 & 100.0 & \\
\hline
\end{tabular}

Note: $p>0.05$. *Not analyzed, as all the participants were suffering from stress.

EG: Experimental Group; EC: Control Group; Pre: Before intervention; Post: After intervention.

Table 2

Index of intragroup stress in the CG, EG and the total sample, before and after the intervention. Rio de Janeiro (RJ), 2008

\begin{tabular}{|c|c|c|c|c|c|c|c|c|c|}
\hline \multirow{2}{*}{ Timing } & \multicolumn{3}{|c|}{ Total sampe } & \multicolumn{3}{|c|}{$E G$} & \multicolumn{3}{|c|}{ CG } \\
\hline & Frequence & $\%$ & $p$ & Frequence & $\%$ & $p$ & Frequence & $\%$ & $p$ \\
\hline Pre & 19 & 100.0 & * & 9 & 100.0 & * & 10 & 100.0 & * \\
\hline Post & 13 & 68.4 & ${ }^{* *} 0.019$ & 4 & 44.4 & ${ }^{* *} 0.029$ & 9 & 90.0 & 1.000 \\
\hline
\end{tabular}

Note: *Not analyzed, as all the participants were suffering from stress; ${ }^{* *} p<0.05$.

EG: Experimental Group; EC: Control Group; Pre: Before; Post: After. 
groups prior to the intervention, there being no statistically significant difference via the Fisher's Exact Test $(p=1)$. After the intervention, in the EG, there were 5 (55.6\%) participants without stress and $4(44.4 \%)$ in the Resistance phase. As for the CG, there was only 1 (10.0\%) patient with no stress,
$8(80.0 \%)$ in the Resistance phase and 1 (10.0\%) in the Exhaustion phase. No patients were found to be in the alert or near-exhaustion phases in the reassessment, in either group. The statistical analysis, via the Fisher's exact test, showed that there was no significant difference between the groups

Table 3

Stress before and after the period of intervention, by group. Rio de Janeiro (RJ), 2008

\begin{tabular}{|c|c|c|c|c|c|}
\hline Patient & Period & Phase & $\begin{array}{l}\text { Physical symptoms } \\
\text { in the phase }\end{array}$ & $\begin{array}{l}\text { Psychological } \\
\text { symptoms in the phase }\end{array}$ & $\begin{array}{l}\text { Total number of } \\
\text { symptoms }\end{array}$ \\
\hline \multirow{2}{*}{$1 \mathrm{E}$} & Pre & Resistance & 2 & 3 & 14 \\
\hline & Post & Resistance & 2 & 2 & 10 \\
\hline \multirow{2}{*}{$2 \mathrm{E}$} & Pre & Resistance & 6 & 3 & 19 \\
\hline & Post & Resistance & 2 & 3 & 19 \\
\hline \multirow{2}{*}{$3 \mathrm{E}$} & Pre & Resistance & 3 & 1 & 13 \\
\hline & Post & No Stress & 0 & 0 & 10 \\
\hline \multirow{2}{*}{$4 \mathrm{E}$} & Pre & Resistance & 5 & 2 & 11 \\
\hline & Post & No Stress & 0 & 0 & 6 \\
\hline \multirow{2}{*}{$5 \mathrm{E}$} & Pre & Resistance & 4 & 1 & 14 \\
\hline & Post & No Stress & 0 & 0 & 5 \\
\hline \multirow{2}{*}{$6 \mathrm{E}$} & Pre & Near-Exhaustion & 7 & 3 & 24 \\
\hline & Post & Resistance & 3 & 2 & 14 \\
\hline \multirow{2}{*}{$7 \mathrm{E}$} & Pre & Near-Exhaustion & 8 & 3 & 31 \\
\hline & Post & Resistance & 5 & 4 & 29 \\
\hline \multirow{2}{*}{$8 \mathrm{E}$} & Pre & Near-Exhaustion & 7 & 3 & 29 \\
\hline & Post & No Stress & 0 & 0 & 8 \\
\hline \multirow{2}{*}{$9 \mathrm{E}$} & Pre & Resistance & 6 & 2 & 16 \\
\hline & Post & No Stress & 0 & 0 & 2 \\
\hline \multirow{2}{*}{$1 \mathrm{C}$} & Pre & Resistance & 2 & 3 & 14 \\
\hline & Post & No Stress & 0 & 0 & 6 \\
\hline \multirow{2}{*}{$2 C$} & Pre & Resistance & 4 & 1 & 15 \\
\hline & Post & Resistance & 4 & 2 & 15 \\
\hline \multirow{2}{*}{$3 c$} & Pre & Near-Exhaustion & 5 & 5 & 18 \\
\hline & Post & Resistance & 4 & 3 & 17 \\
\hline \multirow{2}{*}{$4 C$} & Pre & Resistance & 5 & 4 & 22 \\
\hline & Post & Resistance & 4 & 3 & 22 \\
\hline \multirow{2}{*}{$5 C$} & Pre & Resistance & 3 & 2 & 15 \\
\hline & Post & Resistance & 4 & 2 & 11 \\
\hline \multirow{2}{*}{$6 C$} & Pre & Resistance & 3 & 3 & 16 \\
\hline & Post & Resistance & 6 & 3 & 20 \\
\hline \multirow{2}{*}{$7 C$} & Pre & Near-Exhaustion & 5 & 5 & 28 \\
\hline & Post & Resistance & 4 & 3 & 21 \\
\hline \multirow{2}{*}{$8 C$} & Pre & Resistance & 1 & 4 & 10 \\
\hline & Post & Resistance & 2 & 3 & 13 \\
\hline \multirow{2}{*}{$9 \mathrm{C}$} & Pre & Resistance & 4 & 5 & 21 \\
\hline & Post & Resistance & 1 & 4 & 11 \\
\hline \multirow{2}{*}{$10 \mathrm{C}$} & Pre & Near-Exhaustion & 6 & 5 & 40 \\
\hline & Post & Exhaustion & 7 & 9 & 35 \\
\hline
\end{tabular}

120

Note: E: Patient Experimental Group; C: Patient Control Group; Pre: Before intervention; Post: After intervention. 
$(p=0.084)$. Consequently, a reduction in the level (phase) of stress was not observed in the EG after the RBTHP, when compared with the CG.

The analysis of the number of stress symptoms in the $E G$, in the pre-intervention period, revealed a mean of $19.0 \pm 7.3$, with a variance of between 11 and 31 symptoms, while in the CG the corresponding numbers noted a mean of $19.9 \pm 8.7$, varying between 10 and 40 symptoms. The MannWhitney test revealed there was no statistically significant difference between the groups in terms of stress symptoms in the pre-intervention period $(p=0.78)$. After intervention, the EG obtained a mean of $11.4 \pm 8.3$ symptoms, with a minimum of 2 symptoms and a maximum of 29 . The CG obtained a mean of $17.1 \pm 8.1$ symptoms, with a minimum of 6 and maximum of 35 symptoms. As the initial mean (pre-intervention) of symptoms in the EG was equal to 19 and the ending mean (post-intervention) was equal to 11.4, the total mean variation of symptoms (difference between the ending and starting mean number of symptoms), in this group, corresponded to 7.6. In the CG, the starting mean of symptoms was equal to 19.9 and the ending mean (after 13 weeks), was equal to 17.1 , so the mean of the total variance of symptoms in this group equates to 2.8 . Comparing the groups in terms of the total number of post-intervention symptoms, the Mann-Whitney test revealed there was no statistically significant difference $(p=0.065)$. Although the mean of the total variance of symptoms intragroup was 7.6 in the EG and 2.8 in the CG, what can be seen is that, comparing the groups in terms of the total number of symptoms, using the Mann-Whitney test, no statistically significant difference was found ( $p=0.133)$.

The results shown separately by group revealed that, in the $E G$, the symptoms of 8 participants were reduced, no participants demonstrated an increase while just 1 participant continued to have the same number of symptoms. The Wilcoxon test found intragroup statistical significance for the $E G(p=0.012)$. On the other hand, in the CG, 6 participants had reduced symptoms over time, 2 showed an increase while 2 continued to have the same number of symptoms.

\section{Table 4}

Symptoms of stress by patient, before and after the period of intervention, by group. Rio de Janeiro (RJ), 2008

\begin{tabular}{|c|c|c|c|c|c|c|}
\hline \multirow{2}{*}{ Group } & \multicolumn{3}{|c|}{ Symptoms } & \multirow{2}{*}{$\begin{array}{c}p \text { value - Symptoms } \\
\text { Intragroup }\end{array}$} & \multirow{2}{*}{$\begin{array}{l}\text { Average Variance } \\
\text { of Symptoms }\end{array}$} & \multirow{2}{*}{$\begin{array}{l}p \text { value - Variance in } \\
\text { Symptoms - Intergroup }\end{array}$} \\
\hline & Patient & Before & After & & & \\
\hline \multirow{9}{*}{ EG } & $1 \mathrm{E}$ & 14 & 10 & & & \multirow{19}{*}{$p=0.133$} \\
\hline & $2 \mathrm{E}$ & 19 & 19 & & & \\
\hline & $3 \mathrm{E}$ & 13 & 10 & & & \\
\hline & $4 \mathrm{E}$ & 11 & 6 & & & \\
\hline & $5 \mathrm{E}$ & 14 & 5 & ${ }^{*} p=0.012$ & 7.6 & \\
\hline & $6 \mathrm{E}$ & 24 & 14 & & & \\
\hline & $7 \mathrm{E}$ & 31 & 29 & & & \\
\hline & $8 \mathrm{E}$ & 29 & 8 & & & \\
\hline & $9 \mathrm{E}$ & 16 & 2 & \multirow{11}{*}{$p=0.08$} & \multirow{11}{*}{2.8} & \\
\hline \multirow{10}{*}{ CG } & $1 C$ & 14 & 6 & & & \\
\hline & $2 C$ & 15 & 15 & & & \\
\hline & $3 C$ & 18 & 17 & & & \\
\hline & $4 C$ & 22 & 22 & & & \\
\hline & $5 C$ & 15 & 11 & & & \\
\hline & $6 C$ & 16 & 20 & & & \\
\hline & $7 C$ & 28 & 21 & & & \\
\hline & $8 C$ & 10 & 13 & & & \\
\hline & $9 c$ & 21 & 11 & & & \\
\hline & $10 \mathrm{C}$ & 40 & 35 & & & \\
\hline
\end{tabular}

Note: " $p<0.05$

EG: Experimental Group; EC: Control Group; E: Patient Experimental Group; C: Patient Experimental Group. 
Using the Wilcoxon test, there was found to be a difference in the CG after 13 weeks $(p=0.08)$. Consequently, evaluating just the $E G$, a difference was found in the total number of symptoms postintervention, but when compared to the $C G$, no statistical difference was found using the MannWhitney test $(p=0.065)$. The difference between the EG and the CG can be seen separately, by patient, in Table 4.

With regard to the levels of basal blood pressure, initially, the SBP of the EG and the CG were compared, measured before the sessions (SBPpre), the $E G$ obtained a mean of $124.5 \pm 12.7$, with a minimum of $102.0 \mathrm{mmHg}$ and maximum of 142.2 $\mathrm{mmHg}$. The CG obtained a mean of $123.4 \pm 9.6$, with a minimum of $110.8 \mathrm{mmHg}$ and maximum of $143.3 \mathrm{mmHg}$. As for the mean DBP measured before the sessions (DBP-pre), in the EG, a mean of $82.3 \pm 11$ was identified, with a minimum of $62.8 \mathrm{mmHg}$ and maximum of $97.1 \mathrm{mmHg}$. The $\mathrm{CG}$ exhibited a mean of $81.3 \pm 5.2$, with a minimum of $74.2 \mathrm{mmHg}$ and maximum of $89.3 \mathrm{mmHg}$. Subsequently, a comparative analysis was conducted using the Anova test for repeated SBP and DBP measurements between the $E G$ and the $C G$ before intervention, at the beginning of each session, revealing no difference (SBP: $p=0.73 ; \mathrm{DBP}: p=0.838$ ). The same test was performed comparing the groups, with the pre-session values at the end of the intervention and again no difference was found between the groups (SBP: $p=0.312$; DBP: $p=0.19$ ). There was, therefore, no significant SBP-pre or DBP-pre variance between the $E G$ and the $C G$ neither before nor after the intervention. Similarly, with regard to the postsession SBP and DBP, the Anova analysis was performed for repeated measurements comparing $E G$ and $C G$, which did not reveal a significant difference between the groups (SBP: $p=0.329$; DBP: $p=0.212$ ). Accordingly, no significant post SBP or post $D B P$ variance was found between the $E G$ and the $C G$, neither before nor after the intervention.

In addition, in the EG, an analysis was performed of the variance in pressure between the start and end of each session. To this end, the pressure variance (difference between starting and 122 ending blood pressure) was initially calculated in each RBTHP session and then the mean pressure variance was calculated for the 13 sessions. As far as the SBP is concerned, a mean of $2.8 \pm 5.96$ was found, lying between a minimum value of -4.4 and a maximum of 15.6. The t-test, applied to this variable in the EG, obtained a result of $p=0.196$, a statistically insignificant outcome. The DBP, on the other hand, had a mean variance of $3.14 \pm 3.9$, with minimum and maximum values of -2.7 and 8.2 , respectively. For the mean $D B P$ variance, in the $E G$, the t-test showed $p=0.041$, demonstrating the presence of statistical significance for this variable. The result shows that, for SBP, there was no significant variance before and after the sessions, in the EG, based on the mean variance in each session. As for the DBP, a statistically significant variance was found, denoting an increase in the levels. Table 5 displays the results relating to the CG (which was not subjected to intervention): mean of the SBP-pre and DBP-pre means each week and the means of the "pre" means for every week during the period of study.

\section{Discussion}

The most significant results observed in this study relate to the physical and psychological symptoms associated with stress in the EG. It is

\section{Table 5}

Mean SBP pre and DBP pre in the CG each week and over the total period

\begin{tabular}{|c|c|c|c|c|}
\hline Weeks & SBP & Mean SBP Pre & DBP & Mean DBP Pre \\
\hline 1 & 128.25 & & 80.71 & \\
\hline 2 & 123.15 & & 80.40 & \\
\hline 3 & 127.65 & & 83.35 & \\
\hline 4 & 122.00 & & 82.70 & \\
\hline 5 & 122.25 & & 80.45 & \\
\hline 6 & 124.00 & & 80.00 & \\
\hline 7 & 123.32 & 123.4 & 76.35 & 81.3 \\
\hline 8 & 120.54 & & 82.23 & \\
\hline 9 & 124.00 & & 83.85 & \\
\hline 10 & 124.40 & & 83.33 & \\
\hline 11 & 119.85 & & 83.00 & \\
\hline 12 & 120.75 & & 80.00 & \\
\hline 13 & 124.60 & & 81.00 & \\
\hline
\end{tabular}

Note: SBP: Systolic Blood Pressure; DBP: Diastolic Blood Pressure; Pre: Before intervention. 
possible that the reduction in the rate of stress symptoms found in the EG can be attributed to the RBTHP to which it was subjected, as it was only this group that saw an improvement in the stress index when comparing pre- and post-intervention. This outcome supports the findings of Sheu et al. (2003), who emphasized that the relaxation response may contribute to a reduction in anxiety and other negative, psychological reactions attributable to stress. The intragroup outcome in the EG also corroborates the studies performed by Lipp (1991, 2007) and Lucini et al. (2008), in which deep, diaphragm breathing and muscular relaxation, applied in combination and together with other resources, have been shown to be useful strategies for controlling excessive stress. In the case of the present study, it is speculated that a sample with a larger number of participants would permit statistical significance to be obtained in intergroup comparisons.

Evaluating the EG by itself, an improvement was seen in the stress index, i.e. in the overall number of stressed individuals, but when compared to the $C G$, there was no improvement in stress levels for those who continued to be stressed. One hypothesis to explain this fact is that the external and internal sources of stress in some patients have persisted during the period of the study, acting to sustain the levels of stress. According to the theories of Selye (1965) and Lipp (2003), in the second phase of stress, the individual's capacity to resist is considerably higher in order to regain the equilibrium lost in the first phase (Alert). The organism continues trying to maintain homeostasis and, if the stressor ceases or the individual succeeds in benefiting from coping strategies, the stress process may be interrupted in this phase. In the sample researched, basically composed of participants coming from the more deprived communities close to the location of the study (CMSMC), it was possible to find that the participants were exposed to social stressors such as unemployment, lack of adequate housing conditions, violence in the community, family problems arising from unfavorable financial situations, amongst others. Social stressors like these, already studied in some depth by Gandarillas, Câmara, and Scarparo (2005), are capable of acting as external sources of stress, precipitating it or simply maintaining the clinical condition.

Another possible explanation to enable an understanding of the reason for which the level of stress in the EG, compared with the CG, did not decrease, is that perhaps the techniques of relaxation and breathing are not sufficient to exert an effect on these stressors; i.e. it is possible that the technique is effective in reducing the index and the symptoms of stress through psycho-physiological alterations, but not in acting on psychosocial and internal stressors so as to eliminate stressors objectively and restructure erroneous evaluations of events and distorted cognitions which could be at the core of the clinical stress condition (R.S. Lazarus \& D.N. Lazarus, 1994; Lipp, 2001; Lipp \& Malagris, 2011; Malagris, 2004; Lipp, Malagris, \& Novais, 2007). Possibly a sample with a higher number of participants could clarify the results in order to provide a better explanation.

As far as the BP variable is concerned, a statistical analysis found that the groups were comparable at the start of the study. Contrary to the hypothesis postulated, that there would be a reduction in $\mathrm{BP}$, it was found that, in fact, there was no reduction in SBP. There was also no increase in DBP over time. The explanation for this fact may lie in two hypotheses. The first relates to the environmental conditions, often unfavorable to the performance of the sessions, such as noise and unsuitable temperatures which, unfortunately, were not possible to control. The second hypothesis relates to the variances which occur differently in SBP and DBP in hypertensive patients and is supported by the study of Lipp, Frare, and Santos (2007) which concluded that one might change while the other remained unaltered. The variances in SBP and DBP, according to these authors, are linked to the specific, experimental situation and to the patient's psychological characteristics. The authors noted that unassertive individuals, who have difficulty in asserting their own rights and expressing their thoughts, feelings and beliefs in a direct, clear, sincere and context-relevant manner, 
so as not to violate the rights of other individuals, and/or alexithymic individuals, who have difficulty in articulating emotions and describing feelings and bodily sensations, exhibited a larger variance in DBP when asked to express themselves in terms of their feelings, as well as a larger variance in SBP when asked to inhibit their feelings in situations of interpersonal stress and to control themselves emotionally so as not to express their emotions. In the present study, the participants received stimuli to express their opinions and feelings about the training, their existing difficulties and applications in day-to-day situations of stress. The increase in DBP in the EG may be explained by them being encouraged to express feelings and ideas, examined in the participants at the end of each session.

In addition to these explanations, the literature points to the discoveries made by the Hypertension Intervention Pooling Project (Kaufmann et al., 1988). which conducted a survey with 12 intervention studies involving the relationship between the PMR technique and BP. This survey demonstrated that no significant change in SBP was found, merely a reduction of $2 \mathrm{mmHg}$ in the DBP in association with non-pharmacological interventions, using relaxation. It can be seen that the outcome of the present study, as far as the SBP is concerned, is similar to other interventions carried out. On the other hand, with regard to DBP, the results found here depart somewhat from these other interventions. Nevertheless, it must be borne in mind that, in the survey of interventions performed using the relaxation technique described above, the reduction observed in DBP was small and insignificant.

While on the subject of the BP variable, another issue to be highlighted concerns the performance of muscle contraction exercises which are part of the Progressive Muscular Relaxation technique. This technique has hemodynamic repercussions and may cause an increase in arterial pressure if the contraction is kept up. In other words, sustained muscular contraction for a long period acts like a tourniquet, preventing the blood from reaching the muscle, thereby increasing the pressure 124 (Mota, Barreto, Bin, Simões, \& Campbell, 2008). In this regard, it was noted that a number of patients had difficulty in carrying out specific muscle group exercises although they were frequently instructed on how to carry out the movements correctly, these patients became distracted and maintained a different rhythm from the others, the muscles contracting for longer than the defined period of time. It is speculated that the maintenance of isometric muscle contraction observed in some patients could, together with the expression of emotions, have caused the rise in the DBP, found uniquely in the EG.

In conclusion, the present study found that the RBTHP promoted a reduction in the stress index of the EG participants and also in the full sample, when taking into account the pre- and postintervention periods. The effect of the RBTHP, moreover, had repercussions on the number of stress symptoms. These results corroborate earlier studies which recommend the use of relaxation and breathing techniques for managing emotional stress. Nevertheless, other types of intervention are necessary for individuals to learn how to restructure distorted cognitions and better manage internal sources of stress.

A number of limitations were observed in the study, such as non-random distribution and a small sample size, inappropriate conditions in the location of the study, idiosyncratic ways of carrying out the exercises, sustaining muscular contraction beyond the recommended time limit, amongst others. It is therefore suggested that this study should act as a basis for the performance of fresh studies on the topic which can take into consideration the facts noted here.

So the Relaxation and Breathing Training for Hypertensive Patients has been identified as a beneficial strategy in controlling stress. As a nonpharmacological strategy in the treatment of hypertension, however, it was not regarded as capable of reducing SBP levels. It is recommended, therefore, that effective non-pharmacological treatment of the illness should involve other strategies that complement relaxation and breathing, such as changes in lifestyle and the learning of behavioral and cognitive techniques to 
control stress. These results may contribute to the clarification of the effects of possible strategies used to support the treatment of SAH, so that increasingly effective treatments may be developed.

\section{References}

Carson, A. P., Howard, G., Burke, G.L, Shea, S., Levitan, E. B., \& Muntner, P. (2011). Ethnic differences in hypertension incidence among middle-aged and older U. S. Adults: The multi-ethnic study of atherosclerosis. Hypertension, 57(6), 1101-1107. Retrieved January, 20, 2014, from <http://www.ncbi.nlm.nih.gov/pmc/ articles/PMC3106342/pdf/nihms291362.pdf>.

Daugherty, S. L., Frederick A., Masoudi, F. A., Ellis, J. L., Ho, P.M., Schmittdiel, J.A., et al. (2011). Age dependent gender differences in hypertension management. Journal Hypertension, 29(5), 1005-1011. Retrieved January, 20, 2014, from <http://www.ncbi.nlm. nih.gov/pmc/articles/PMC $3319751 / p d f / n i h m s$ 366688.pdf>.

Davis, M., Eshelman, E. R., \& McKay, M. (2000). The relaxation and stress reduction workbook. Oakland: New Harbinger Publications.

Forman, J., P., Stampfer, M. J., \& Curhan, G. C (2009). Diet and lifestyle risk factors associated with incident hypertension in women. Journal of the American Medical Association, 302(4), 401-411. Retrieved January, 20, 2014, from <http://www.ncbi.nlm. nih.gov/pmc/articles/PMC2803081/pdf/nihms163647.pdf>.

Gandarillas, M. A., Câmara, S. G., \& Scarparo, H. (2005). Estressores sociais da hipertensão em comunidades carentes. Psicologia: Reflexão e Crítica, 18(1), 62-71.

Grossman, E., Grossman, A., Shein, M. H., \& Zimlichman, R. (2001). Breathing-control lowers blood pressure. Journal of Human Hypertension, 15(4), 263-269.

Jacobson, E. (1938). Progressive relaxation. Chicago: University of Chicago Press.

Jacobson, E. (1993). Relax: como vencer as tensões. São Paulo: Cultrix.

Khan, N. A., Hemmelgarn, B., Padwal, R., Larochelle, P., Mahon, J. L., Lewanczuk, R. Z., et al. (2007). The 2007 Canadian hypertension education program recommendations for the management of hypertension: Part 2 - therapy. Canadian Journal of Cardiology, 23(7), 539-550. Retrieved January, 21, 2014, from <http:// pubmedcentralcanada.ca/pmcc/articles/PMC2650757/>.

Kaufmann, P. G., Jacob, R. G., Ewart, C. K., Chesney, M. A.,Muenz, L. R., Doub, N., et al. (1988). Hypertension intervention pooling project. Health Psychology, 7(Suppl.), 209-224.
Larkin, K. T. (2005). Stress \& Hypertension: Examining the relation between psychological stress and high blood pressure. New Haven: Yale University Press.

Lazarus, R. S., \& Folkman, S. (1984). Stress, appraisal, and coping. New York: Springer.

Lazarus, R. S., \& Lazarus, B. N. (1994). Passion and reason: Making sense of our emotions. New York: Oxford University Press.

Lipp, M. E. N. (1991). O valor do controle do stress como terapêutica da hipertensão arterial. In M. Nobel. Psicossomática (pp.83-162). Campinas: NEP.

Lipp, M. E. N. (2000). Inventário de Sintomas de Stress para Adultos de Lipp - ISSL. São Paulo: Casa do Psicólogo.

Lipp, M. E. N. (2001). Estresse emocional: a contribuição de estressores internos e externos. Revista de Psiquiatria Clínica, 28(6), 347-349.

Lipp, M. E. N. (2003). O modelo quadrifásico do stress. In M. E. N. Lipp (Org.), Mecanismos neuropsicofisiológicos do stress: teoria e aplicações clinicas (pp.17-21). São Paulo: Casa do Psicólogo.

Lipp, M. E. N. (2005). Manual do Inventário de Sintomas de Stress para Adultos de Lipp (ISSL). São Paulo: Casa do Psicólogo.

Lipp, M. E. N. (2007). Controle do estresse e hipertensão arterial sistêmica. Revista Brasileira de Hipertensão, 14(2), 89-93.

Lipp, M. E. N., Frare, A., \& Santos, F. U. (2007). Efeitos de variáveis psicológicas na reatividade cardiovascular em momentos de stress emocional. Estudos de Psicologia (Campinas), 24(2), 161-167. doi: 10.1590/S0103166X2007000200003

Lipp, M. E. N., \& Malagris, L. E. N. (2001). O stress emocional e seu tratamento. In B. Rangé (Org.), Psicoterapias cognitivo-comportamentais: um diálogo com a psiquiatria (pp.475-490). Porto Alegre: Artmed.

Lipp, M. E. N., \& Malagris, L. E. N. (2011). Estresse: aspectos históricos, teóricos e clínicos. In B. Rangé (Org.), Psicoterapias cognitivo-comportamentais: um diálogo com a psiquiatria (pp.617-632). Porto Alegre: Artmed.

Lipp, M. E. N., Malagris, L. E. N., \& Novais, L. E. (2007). Stress ao longo da vida. São Paulo: Ícone.

Lipp, M. E. N., \& Rocha, J. C. (1994). Stress, hipertensão arterial e qualidade de vida: um guia de tratamento para o hipertenso. Campinas: Papirus.

Lipp, M. E. N., \& Rocha, J. C. (2008). Pressão alta e stress: o que fazer agora? Um guia de vida para o hipertenso. Campinas: Papirus.

Lucini, D., Riva, S., Pizzinelli, P., \& Pagani, M. (2008). Controle do estresse no local de trabalho: reversão do perfil de sintomas e da desregulação cardiovascular. Revista Brasileira de Hipertensão, 1(2), 66-73. 
Malagris, L. E. N. (2004). Correr, competir, produzir e se estressar. In M. Lipp (Org.), O stress está dentro de você (pp.19-31). São Paulo: Contexto.

Malagris, L. E., Brunini,T. M. C., Moss, M. B., Silva, P. J. A., Espósito, B. R., \& Ribeiro, A. C. M. (2009). Evidências biológicas do treino de controle do stress em pacientes com hipertensão. Psicologia: Reflexão e Crítica, 22(1), 60-68. Recuperado em janeiro, 20, 2014, disponível em <http://www.scielo.br>.

Mion Jr., D., Kohlmann Jr., O., Machado, C. A., Amodeo, C., Gomes, M. A. M., Paxedes, J. N., et al. (Coords.) (2007). V Diretrizes Brasileiras de Hipertensão Arterial. Arquivos Brasileiros de Cardiologia, 89(3), 24-79.

Mota, Y. L., Barreto, S. L., Bin, P. R., Simões, H. G., \& Campbell, C. S. G. (2008). Respostas cardiovasculares durante a postura sentada da Reeducação Postural Global (RPG). Revista Brasileira de Fisioterapia, 12(3), 161-168.

Pimenta, E., Calhoun, D., \& Oparil, S. (2007). Mechanisms and treatment of resistant hypertension. Arquivos Brasileiros de Cardiologia, 88(6), 604-613.

Pinheiro, C. H. J., Medeiros, R. A. R., Pinheiro, D. G. M., \& Marinho, M. J. F. (2007). Modificação do padrão respiratório melhora o controle cardiovascular na hipertensão essencial. Arquivos Brasileiros de Cardiologia, 88(6), 576-583.

Pugliese, R., Zanella, M. T., Blay, S. L., Plavinik, F., Andrade, M. A., \& Galvão, R. (2007). Eficácia de uma intervenção psicológica no estilo de vida para redução do risco coronariano. Arquivos Brasileiros de Cardiologia, 89(4), 225-230.

Sandberg, K., \& Ji, H. (2012). Sex differences in primary hypertension. Biology of Sex Differences, 3(7), 1-21. Retrieved January, 20, 2014, from <http://www. ncbi.nlm.nih.gov/pmc/articles/PMC 3331829/pdf/ 2042-6410-3-7.pdf>.
Selye, H. (1965). Stress: a tensão da vida. São Paulo: Ibrasa.

Sheu, S., Irvin, B. L., Lin, H.-S., \& Mar, C.-L. (2003). Effects of progressive muscle relaxation on blood pressure and psychosocial status for clients with essential hypertension in Taiwan. Holistic Nursing Practice, 17(1), 41-47.

Sociedade Brasileira de Cardiologia, Sociedade Brasileira de Hipertensão, \& Sociedade Brasileira de Nefrologia (2010). VI Diretrizes Brasileiras de Hipertensão Arterial. Arquivos Brasileiros de Cardiologia, 95(1 Supl. 1), 1-51.

Souza, A. C. C., Moreira, T. M. M., Borges, J. W. P., Andrade, A. M., Andrade, M. M., \& Almeida, P. C. (2009). Caracterização clínico-epidemiológica da clientela com crise hipertensiva atendida em um serviço de emergência de um hospital municipal de Fortaleza-CE. Revista Mineira de Enfermagem,13(1), 13-18.

Straub, R. O. (2005). Psicologia da saúde. Porto Alegre: Artmed.

Thalenberg, J. M. (2006). Teste de respiração lenta no diagnóstico da hipertensão do avental branco (Tese de doutorado não-publicada). Programa de Pós-Graduação em Medicina Interna e Terapêutica, Universidade Federal de São Paulo.

Thalenberg, J. M., Póvoa, R. M. S., Bombig, M. T. N., Sá, G. A. C., Atallah, A. N. A., \& Filho, B. L. (2008). Teste de respiração lenta aumenta a suspeita da hipertensão do avental branco no consultório. Arquivos Brasileiros de Cardiologia, 91(4), 267-273.

Received on: 15/12/2011

Final version on: 20/6/2012

Approved on: 6/7/2012 